\title{
Corporate Social and Environmental Strategy and Reporting in Indonesian Plantation Industry
}

\author{
Intan Belinda Lestari* (10) | Noradiva Hamzah² | Ruhanita Maelah³ \\ ${ }^{1}$ Universiti Kebangsaan Malaysia, Faculty of Economics and Management, Bangi, Malaysia \\ ${ }^{2}$ Universiti Kebangsaan Malaysia, Faculty of Economics and Management, Bangi, Malaysia \\ 3 Universiti Kebangsaan Malaysia, Faculty of Economics and Management, Bangi, Malaysia
}

*Correspondence to: Intan Belinda Lestari, Universiti Kebangsaan Malaysia, Faculty of Economics and Management, Bangi 43600, Selangor, Malaysia.

E-mail: intanbelindalestari@ymail.com

\begin{abstract}
This study aims to investigate how corporate social and environmental strategy can contribute to corporate social and environmental reporting (CSER) in the plantation industry in Indonesia. This study employed a case study approach by using semi-structured interviews to collect data from Indonesian plantation companies listed in the Indonesia Stock Exchange (IDX) and stateowned plantation companies that included CSER in their annual report. The motivation of CSER implementation in Indonesian plantation companies was influenced by proactive and reactive strategies. The corporate social and environmental strategy of proactive principles would publish CSER due to the social discretion beyond the regulatory requirements or pressure of certain stakeholders, and prior to any negative information being received by the public. Moreover, the corporate social and environmental strategy of reactive principles would also publish CSER to meet stakeholders' needs and demands, obtain good corporate image and reputation, and avoid negative impacts (e.g., harm, hazards, mishap, complaints, etc.). Therefore, corporate social and environmental strategy can contribute to CSER depending on whether the company has proactive or reactive principles. This research contributes to the knowledge of social accounting literature in which CSER practices can be influenced by corporate social and environmental strategy.
\end{abstract}

Keywords: corporate social and environmental reporting, disclosure, resource-based view theory, strategy.

Article info: Received 12 March 2019| revised 29 April 2019| accepted 24 May 2019

Recommended citation: Lestari, I. B., Hamzah, N., \& Maelah, R. (2019). Corporate Social and Environmental Strategy and Reporting in Indonesian Plantation Industry. Indonesian Journal of Sustainability Accounting and Management, 3(1), 84-94. https://doi.org/10.28992/ijsam.v3i1.80.

\section{INTRODUCTION}

In recent years, the global awareness of social and environmental issues has increased and it affects firms' perspectives on their social and environmental sensitivity (Jayanti \& Gowda, 2014; Weng et al., 2015). For that reason, social and environmental concepts have eventually begun to become accountable through disclosure in traditional corporate annual reports. Corporate Social and Environmental Reporting (CSER) is exhibited through corporate social and environmental disclosure. This reporting is regarded as a driver for a successful 
organization as it is linked to a superior financial profile through the disclosure of corporate social and environmental performance (Faboyede, 2011). Most studies also engaged the CSER objective for the attainment of sustainable development (Daniel et al., 2015; Famiyeh et al., 2016).

Due to the multiple benefits of applying CSER, some studies investigated the best corporate social and environmental strategy to enhance the adoption of this reporting. Various authors have classified the elements of corporate social and environmental strategy, ranging from passive, reactive, and proactive (Henriques \& Sadorsky, 1999; Sambasivan et al., 2013). A proactive company would voluntarily implement its responsible social and environmental practices (Garcés-Ayerbe et al., 2012). A reactive company only implements social and environmental practices to respond to the demands of common stakeholders, whereas a passive company does not (Torugsa et al., 2013). Based on this explanation, passive principles are not suitable to support the implementation of this social and environmental disclosure. Accordingly, only proactive and reactive strategies can probably improve CSER practices.

However, the conclusion of previous studies showed different results. Barba-Sánchez \& AtienzaSahuquillo (2016) found that the degree of proactivity in corporate strategy had a greater impact on improving corporate environmental responsibility. The motivations of CSER adoption are not merely based on the regulatory requirements or the pressure of stakeholders, but by the social discretion that emerges from a sense of corporate ethical responsibility among executives (Menguc \& Ozanne, 2005; Calza et al., 2016). As a consequence, corporate social proactivity is often regarded as the best approach for organizations because they would actively engage corporate social and environmental responsibility beyond the stakeholders' demands such as regulation and law. In contrast, Fang et al. (2010) stated that a reactive strategy could motivate the management of an organization to implement its corporate social and environmental responsibility through the demands of stakeholders or regulatory requirements. Additionally, Flammer (2013) discovered that external factors (i.e., regulations and related issues) could influence CSER improvements. Meanwhile, Hossain et al. (2017) argued that the motivations of CSER could be underpinned by a proactive or reactive strategy. Hence, this study will explore the role of both corporate social and environmental strategies (proactive and reactive) on CSER implementation.

The relationship between corporate social and environmental strategy and CSER will be explained by using the Resource-based View (RBV) theory. This theory clarifies how organizations achieve a competitive advantage and superior performance by using their capabilities to manage resources (Aragón-Correa et al., 2008). Wang (2014) described that competitive advantage is a key determinant of outperforming competitors, while capability is defined as a source of competitive advantage and resource is a source of capability. Resource could be categorized into knowledge-based (such as skill, knowledge, quality, and competency) and propertybased (such as physical asset, financial capital, and human capital), tangible and intangible, etc. (Rasi et al., 2014, Yu \& Ramanathan, 2016). Capabilities are defined as a firm's capacity and ability to deploy, build, and reconfigure resources to affect a desired end (Haas \& Hansen, 2005). Some studies argued that capabilities are part of any strategy within a firm (Wang, 2014). Powell (2001) stated that business strategy can be viewed as a tool to manipulate some resources to create a competitive advantage. Figure 1 shows the framework of this study.

Corporate Social and

Environmental Strategy

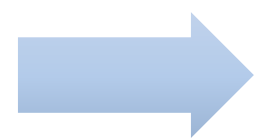

Corporate Social and

Environmental Reporting

Figure 1 Research Framework 
Indonesia is one of many countries that are concerned about environmental and social issues related to a company's responsibility. For example, Indonesia has issued some programs and acts related to CSER. One of the programs that support CSER is PROPER (Indonesia's program for pollution control, evaluation, and rating). This program is built to promote industrial compliance with pollution control regulations, to facilitate and enforce the adoption of practices contributing to 'clean technology', and to ensure a better environmental management system by assessing corporate environmental performance ratings. Indonesia has also enacted Act 40/2007 and Act 32/2007 that require each company to fulfill its social responsibility and dicslose its social and environmental responsibilities in the annual report. However, the data from PROPER in 2015 showed that only $1 \%$ of companies achieved a gold rating as a symbol of best environmental performance. In 2015, Indonesia still had the massive forest fire problem that occurred in Sumatra and Kalimantan and caused toxic haze to spread to other parts of Southeast Asia.

In contrast, Groza et al. (2011) found that stakeholder pressure significantly motivated management in organizations to adopt certain social and environmental practices. For example, regulation requirements, community protests, customer and investor demands force managements to be aware of social and environmental issues and to follow the rules. However, the perspective of managers is also an important factor when applying social and environmental strategies and programs. Hossain \& Alam (2016) observed that the point of view on corporate social obligation in a manager's perspective could motivate CSER practices in organizations.

There is a difference between a theory or empirical evidence and actual evidence in Indonesian companies, especially those involved in the plantation industry. Corporate social and environmental disclosure in Indonesian listed companies were still low (Oeyono et al., 2011; Djajadikerta \& Trireksani, 2012), and deforesation problems are also getting worse in Indonesia, despite sufficient support from the government. The decision to increase corporate social responsibility must arise from self-awareness of companies regarding the implementation of a regulatory system in Indonesia, which is still ineffective. Therefore, this study aims to investigate this gap. Does corporate social and environmental strategy influence corporate social and environmental reporting? How does corporate social and environmental strategy influence corporate social contribution to corporate social and environmental reporting?

\section{METHODS}

This study employed a case study methodology with semi-structured interviews. Six plantation companies that were listed in the IDX and had issued CSER in their annual report were selected as the participants in this study. These six companies consisted of three companies of proactive strategy and the rest were of reactive strategy. Managers were selected as interviewees because they are regarded as knowledgeable people concerning their respective firms (Yu \& Ramanathan, 2016).

The interview was conducted face to face and direct, in which the informant was guided by an interviewer to unlock hidden motivations, beliefs, behaviors, and feelings related to the corporate social and environmental strategy and CSER practices. This type of interview attempts to get the respondent to talk freely and to express his/her true feelings (lacobucci \& Churchill Jr., 2018). The interview was carried out from March till July 2018, and lasted between 60 to 90 minutes each. All of the interview data were recorded on an electronic audiotape, then the records were transcribed and checked. Table 1 presents the background of companies that participated in this study. 
Table 1 Background of Companies for Case Study

\begin{tabular}{|c|c|c|}
\hline Company ID & Company Status & Business Activities \\
\hline Company A & $\begin{array}{l}\text { State-owned enterprise } \\
\text { (SOE) plantation }\end{array}$ & Cultivates and produces palm oil, rubber, tea, and sugar cane. \\
\hline Company B & Public plantation company & Cultivates palm oil, sugar cane, rubber, and other crops. \\
\hline Company C & $\begin{array}{l}\text { State-owned enterprise } \\
\text { (SOE) plantation }\end{array}$ & $\begin{array}{l}\text { Cultivates plants, produces, trades, and develops the plantation business } \\
\text { of oil palm and rubber. }\end{array}$ \\
\hline Company D & Public plantation company & Cultivatives and processes palm oil, rubber, sugar cane, and other crops. \\
\hline Company E & $\begin{array}{l}\text { State-owned enterprise } \\
\text { (SOE) plantation }\end{array}$ & $\begin{array}{l}\text { Cultivate plants, clears lands, and prepares, plants, maintains, and } \\
\text { performs marketing of planting commodities. }\end{array}$ \\
\hline Company F & Public plantation company & $\begin{array}{l}\text { Cultivates and produces oil palm, rubbber, oil palm seeds, and other } \\
\text { crops. }\end{array}$ \\
\hline
\end{tabular}

This study used the interview items built with combinative knowledge from previous studies. For instance, the instrument of corporate social and environmental strategy replicated some prior studies (Galbreath, 2009; Wagner et al., 2009; Groza et al., 2011; Torugsa et al., 2013; Sambasivan et al., 2013; Dahlander \& Piezunka, 2014; Hossain et al., 2017) to determine the level of proactivity or reactivity of firms' strategy through the integration of several basic principles in terms of social and environmental management into their overall business strategy.

In terms of data analyzing, this study conducted a cross-case analysis. First, the data obtained in the interview were divided into categories and sub-categories that were deemed possibly influential in CSER strategies. Then, the transcribed data were re-read and the themes that emerged at this stage within the framework were recorded beside the relevant selection of interview transcript by using a set of intuitively derived codes for each apparent theme. This coding method is defined by Richards \& Morse (2012) as the technique of changing messy textual data into organized ideas about the events that occured. Furthermore, the cross-case analysis was conducted by analyzing the evidence across the six plantation companies in this research. The findings were summarized, compared, and analyzed across different companies. According to Miles et al. (2013), the benefits of a cross-case analysis are to understand the process and consequences across many cases, to see how they are restricted by local circumstances, and to obtain more sophisticated descriptions and more powerful explanations.

In order to evaluate the quality of data collection, this study carried out the realibility test. This test also aims to minimize the errors and biases in a study (Yin, 2017). This study adopted Fleiss (1971) to assess data reliability. This is a statistical measurement for assessing the reliability agreement for any number of raters that give categorical ratings to a fixed number of classifying items.

\section{RESULTS AND DISCUSSION}

Based on the evidence obtained from the interviews and documentation, the six plantation companies were grouped into strategies that consisted of proactive and reactive. Companies $A, D$, and $F$ were classified as proactive, whereas companies B, C, and E were classified as reactive.

\section{Proactive CSER Strategy}

The findings of the interviews revealed that companies $A, D$, and $F$ were proactive companies as they conducted CSER based on their intention, which was dominated by social discretion to be responsible in terms 
of social and environmental. These companies did not consider that regulation and requirements from the stakeholders were the primary motivations for them to implement CSER. Furthermore, all these companies assumed that CSER was their opportunity to contribute to help enhancing the society's prosperous and disadvantaged people, as well as protecting the sustainability of the environment. The managers gave their opinions as below:

"I think what the government has done, it is not a pressure. We also didn't get any pressure from stakeholders, but we still have to implement CSER programs. Although there is no force from any parties [...] CSER is one of the corporate contributions to society in increasing their welfare" (Company A).

"This reporting is corporate obligation, especially for public companies. We should care about our environment and society, not only financial aspects. Since the 1990s, this company has conducted CSER practices, even though it hasn't been a mandatory regulation. It is because we want to help people's lives and hope their welfare going to improve their welfare" (Company D).

"Organizations need the society, they should take care of their stakeholders, especially local communities, poor people, and the society at large. As for the environment, the effect of environment could be bigger if companies are not taking care of it. Therefore, taking care of the society and environment is the part of a company's contribution" (Company F).

Based on these statements, companies with a proactive strategy have more sympathy and empathy for their society and environment. Thus, the motivation of a proactive company is more dominated by social discretion that emerges among executives (Menguc \& Ozanne, 2005; Calza et al., 2016). In addition, the findings showed that companies with proactive principles have more understanding of their responsibility on CSER adoption. The managers stated that:

"A corporation is an Agent of Development or the arm of the government. Therefore, the company has a duty towards the development and empowerment of society in the company's environment, either in the case of economy development or empowering the society and community, in order to improve their welfare" (Company A).

"Because we (company) understand that we couldn't grow alone. If the company wants to be successful and well developed, we should always help them. Then, we can grow up together" (Company D).

"CSER is a company's responsibility to always undertake that practice. Accordingly, a company should give contribution toward the environment and society at large, in order to create a sustainable business" (Company F).

These statements indicated that companies with proactive strategy were aware of CSER. These companies understood that CSER was their responsibility because they realized that a corporation is part of the society and they were unable to grow alone without support from the society. Hence, they would likely not forget their responsibilities, including to disclose CSER. As Torugsa et al. (2013) mentioned, a company with proactive strategy would undertake CSER beyond regulatory requirements and prior to any pressure from stakeholders.

The interviews also explained how corporate social and environmental strategies can contribute to CSER in the plantation industry in Indonesia. These companies with proactive strategy acknowledged that the education and knowledge of CSER were important to encourage the adoption of this reporting. The managers said that:

"I think the knowledge of a company really influences the development of CSER. Sometimes, the company is only concerned to boost financial performances. They don't know the negative impacts if the company does not take care of it, which can be related to the company's costs, such as natural disasters, penalties, or punishments" (Company A). 
"I think the knowledge and understanding of CSER concept can enhance this reporting, for example, the concept of sustainability advantage. This concept could educate companies that CSER is not merely related to profit but also the sustainable development for a business in the long term" (Company D).

"In my opinion, the adoption of CSER is influenced by the intention of companies. I think the company should have good knowledge about this reporting to enhance their intention. This is because a lot of benefits will be achieved if they really know about CSER" (Company F).

In terms of these statements, this study concluded that the proactive strategy could contribute to CSER through the education and knowledge of CSER implementation. The role of this CSER knowledge could enhance a company's awareness of the society and environment, and also develop the company's intention to implement this reporting. Thus, the knowledge of CSER is really important to be shared in organizations, universities, and the society at large through seminars, trainings, or studies that are related to social discretion.

\section{Reactive CSER Strategy}

The findings of interviews revealed that companies B, C, and E were classified as reactive. These companies assumed that CSER is a mandatory compliance practice that should be followed by a company to have a good image and reputation with its stakeholders. These reactive companies would conduct CSER based on the requirement and pressure from their stakeholders. They also complied with CSER to avoid some negative impacts, such as harm, hazard, etc. The managers said:

"We could meet our stakeholders' needs by conducting CSER practices. Our CEO said that our investors feel more satisfied and appreciated when they know we support about social and environmental programs. [...] What the company does, it might have an effect on its environment, when the negative impacts happen. The point is the company must do something in terms of taking care of its environment to prevent those negative impacts" (Company B).

"We have to care about those aspects in order to maintain the stability of a company. The more crucial reason a company wants to comply about [with] this CSER requirement is reputation and image. The company could be considered as a good company as it is responsible toward the society and environment" (Company C).

"The advantages of CSER adoption are first the good corporate image; when the public has respect for the company, it will make the company's work being become easier. The company will get a good impact from the institutional relationship with the society and community. The company should also have a good relationship with them to build a harmonious relationship; it will minimize the negative impacts such as protests from other parties" (Company E).

These statements showed that the motivations of reactive strategy encouraged the companies to published CSER to obtain good image and reputation and to avoid some negative impacts. This is similar to Groza et al. (2011), who stated that reactive companies would engage in CSER to protect the image of the organization, for example to mitigate harm. Companies with reactive strategy also assumed that regulatory requirements and stakeholders' pressure played an important role in CSER adoption. The managers gave their opinions as below:

"The pressure of stakeholders could impact the companies. So, I think it is quite impossible for the company to implement CSER without pressure from stakeholders. At least there must be pressure from one of the stakeholders to push the company into adopting this reporting. This is because the company will never do something that does not have any benefit for them" (Company B).

"I think the government holds the important power of this CSER implementation" (Company C). 
"We adopt CSER because for state-owned corporations like us, adopting CSER has been a mandatory aspect from the government [...] Our international customers and investors, they have concerned regarding CSER. They even prefer a company that has shown its social and environmental responsibilities. One of the tough certification is RA (Rainforest Alliance) certification that is always required by our investors and customers" (Company E).

Based on these statements, the reactive strategy was concerned about the corporate reputation and image. Companies with reactive principles also worried about the negative impacts due to the lack of CSER awareness. Thus, the reactive companies would comply with regulatory requirements and pay attention to the stakeholders' demands, in line with Sambasivan et al. (2013) who said that the motivation of an organization with a reactive strategy would be driven by the demand of certain stakeholders such as regulation, law, and so forth.

When the managers of companies B, C, and E were asked on how to encourage CSER implementation in the Indonesian plantation industry, they agreed that the regulatory requirements and stakeholders' pressure would influence companies to disclose CSER. The managers said that:

"Currently, there is a development of sustainable investment that involves the investors, especially lenders such as banks. They will see how the programs of companies solve the social and environmental impacts. They will not invest in a company that has bad track record of its social and environmental issues. The NGO campaigns can also influence companies. There is a plantation company in Indonesia that has started to put more concern on CSER practices because of the negative campaigns from NGOs. NGOs sometimes will attack companies through their suppliers, they will make campaigns to force suppliers to become stricter to those companies regarding social and environmental aspects. So, the plantation companies unavoidably undertake their suppliers' request" (Company B).

"Due to the reason of a company's compliance with CSER requirement is to be judged as a good company, they want to be considered to have a good image or they might want to get rewards from CSER implementation. Then, we still need the society to work together, for example, we need the farmers' palm oil fruits to fulfill our supply. So, the company should take care of its society and environment" (Company C).

"The government could motivate companies to conduct CSER by promising a reward such as bonus, tax reduction, etc. Because CSER application is not easy and cheap, if there is a lack of appreciation for companies, I think it will be quite difficult to encourage companies in implementing this reporting. The government could also push companies to warn them in terms of the punishment or penalties if they did not disclose CSER. For example, we (as state-owned corporations) should comply with CSER because we will get blacklisted by the government" (Company E).

Based on the interviews, it was concluded that companies with reactive strategy would perform something that had either good or bad impacts for them, such as good corporate image and reputation, or rewards and penalties, and so on. Thus, reactive companies would take care of stakeholders' demands (i.e., regulation, law, or investors, suppliers, customers' requirements) because it would eventually have an impact on the company. Therefore, the reactive strategy could contribute to CSER through the stakeholder's demands and eventually give rewards and/or punishment to companies.

\section{CSER of Proactive and Reactive Strategies}

This study adopted the six indicators as suggested by Hossain et al. (2017), namely: 1) community development; 2) governance policy;3) communication strategy; 4) product/service responsibility; 5) workplace; and 6) natural environment, to identify the CSER practices among six plantation companies. The detailed analysis of CSER practices for each of the companies is presented in Table 2. 
Table 2 Detailed Analysis of CSER Practices of Companies

\section{CSER Practices}

1) Community Development

a) Provides educational aid

b) Provides health aid

c) Provides infrastructure development

d) Donates to natural disaster aid

e) Conducts philantrophy activities

f) Provides grant of work capital loan for the society and community

2) Governance Policy

a) Adopts Global Reporting Initiative (GRI) as CSER guidelines

b) Complies with some national and international standards, certifications, and principles

c) There is audit committee involvement in checking CSER activities

d) CSER program refers to government regulation

e) There is an Enterprise Risk Management (ERM) framework

f) Implements self-Integrated Management System to manage CSER

3) Communication Strategy

a) Has sustainability reporting

b) Presents CSER in all forms, including narrative descriptive, table, picture, chart, etc.

c) Discloses CSER in annual report and its official website

d) There is detailed information of GRI content index in the reporting

4) Product and Service Responsibility

a) Maintains health and safety products

i. Protects security in labeling and packaging products

ii. Maintains nutrition of products

b) Maintains quality products

c) Conducts customer and supplier satisfaction surveys

d) Has standard operating procedures (SOP) for customers and suppliers regarding sustainable sourcing and supply chain

5) Workplace

a) Protects employees' rights and obligations in Collective Labor Agreement CLA)

b) Supports freedom of association of employees

c) Offers some trainings to encourage human resource capability and competency

d) There is no descrimination in the workplace

e) There is a concern toward the occupational safety and health (OSH) of employees

f) Fair assessment in measuring employees' performance

6) Natural Environment

a) Concerned to solve forest fire problems

b) Conducts HCV and HCS assessments

c) Maintains water conservation

d) Management of waste

e) Reduces pollution and emission

f) Supports energy efficiency

g) Protects biodiversity sustainability

\begin{tabular}{lllll}
\multicolumn{2}{l}{ Proactive } & \multicolumn{2}{l}{ Reactive } \\
\hline A & D F & B & C
\end{tabular}

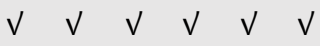

$\begin{array}{llllllllllllll} & V & V & V & V & V & V\end{array}$

$\begin{array}{lllllllllll}V & V & V & V & V & V\end{array}$

$\begin{array}{llllllllllllllll} & V & V & X & V & V & V\end{array}$

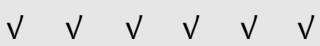

$\begin{array}{lllllll} & V & V & \vee & \vee & V\end{array}$

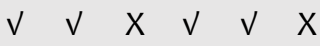

$\begin{array}{lllllllllll} & V & V & V & V & V & V\end{array}$

$\begin{array}{llllll}V & V & V & V & V & V\end{array}$

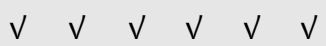

$\begin{array}{lllllllllllllllll} & V & V & V & V & V\end{array}$

$\checkmark \vee V \quad V \quad V \quad V$

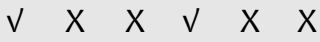

$\begin{array}{llllllllll} & V & V & V & V & V & V\end{array}$

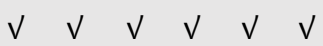

$\checkmark \quad X \quad X \quad \vee \quad X \quad X$

Based on these findings, there is no difference between proactive and reactive companies in carrying out CSER practices. Some proactive and reactive companies still dimissed a few items in CSER. However, most of the companies implemented all the CSER indicators; it could be seen from the numbers of tick symbol that were more than the numbers of cross symbol in Table 2. Company A (proactive strategy) and company B (reactive strategy) performed all of the CSER indicators. These findings indicated that CSER practices could be 
motivated by both corporate social and environmental strategies, namely proactive and reactive. This result is consistent with Hossain et al. (2017), who stated that the motivations of CSER were underpinned by a proactive or reactive strategy.

In conclusion, the answers to the question of how corporate social and environmental strategy contributes to CSER in the plantation industry in Indonesia are divided into two points. First, the corporate social and environmental strategy of a proactive company can influence CSER implemention when the company understands and has knowledge on the impact of this reporting on the society, communities, environment, and planet. Second, the corporate social and environmental strategy of reactive companies can influence CSER adoption when they are pushed by regulation, laws, pressure, complaints, or protests by certain powerful stakeholders, as these companies are really concerned on fulfilling stakeholders' demands and needs, and building a good image and reputation. These findings are supported by some studies (Fang et al., 2010; Torugsa et al., 2013; Sambasivan et al., 2013; Hossain et al., 2017), in which proactive and reactive strategies can influence CSER activities in an organization. Therefore, there is an association between strategy and CSER level of companies.

\section{CONCLUSION}

The findings of this study showed that the motivation of CSER can be underpinned by a proactive or reactive strategy. The corporate social and environmental strategy of proactive companies can influence CSER implemention when the companies understand and have knowledge about the impact of this reporting on the society, communities, environment, and planet. The corporate social and environmental strategy of reactive companies can influence CSER adoption when they are pushed with regulation, laws, pressure, complaints, and protests by certain powerful stakeholders. These findings also supported the theoretical framework, in which there is an association between corporate social and environmental strategy (proactive and reactive) and CSER.

This study can contribute to the knowledge of social accounting literature, whereby CSER practices can be influenced by corporate social and environmental strategy. In addition, the findings of the present study can contribute to refine and develop CSER regulation and programs that can improve the implementation of this reporting in Indonesia, such as providing trainings/seminars/educational programs of CSER, making strict CSER requirements for companies to perform business, or issuing the CSER law with rewards and punishment. This study focused on the corporate social and environmental strategy and CSER practice in the Indonesian plantation industry by investigating the motivation behind companies that have good CSER practices. Future research could re-investigate on more companies (listed and unlisted) to improve CSER in the Indonesian plantation industry.

\section{ORCID}

Intan Belinda Lestari (1) https://orcid.org/0000-0002-6021-8816 


\section{REFERENCES}

Aragón-Correa, J. A., Hurtado-Torres, N., Sharma, S., \& García-Morales, V. J. (2008). Environmental Strategy and Performance in Small Firms: A Resource-Based Perspective. Journal of Environmental Management, 86(1), 88-103. https://doi.org/10.1016/j.jenvman.2006.11.022

Barba-Sánchez, V., \& Atienza-Sahuquillo, C. (2016). Environmental Proactivity and Environmental and Economic Performance: Evidence from the Winery Sector. Sustainability, 8(10). https://doi.org/10.3390/su8101014

Calza, F., Cannavale, C., \& Tutore, I. (2016). The Important Effects of National Culture on the Environmental Proactivity of Firms. Journal of Management Development, 35(8), 1011-1030. https://doi.org/10.1108/JMD10-2015-0145

Dahlander, L., \& Piezunka, H. (2014). Open to Suggestions: How Organizations Elicit Suggestions through Proactive and Reactive Attention. Research Policy, 43(5), 812-827. https://doi.org/10.1016/j.respol.2013.06.006

Daniel, A. A., Adewumi, A. R., \& Adeyinka, A. J. (2015). Environmental Accounting - A Tool for Sustainable Development. International Journal of Advanced Academic Research, 1(2).

Djajadikerta, H. G., \& Trireksani, T. (2012). Corporate Social and Environmental Disclosure by Indonesian Listed Companies on Their Corporate Web Sites. Journal of Applied Accounting Research, 13(1), 21-36. https://doi.org/10.1108/09675421211231899

Faboyede, O. S. (2011). Environmental Protection and Sustainability Reporting: Extensible Business Reporting Language (XBRL) Interactive Data to the Rescue. Journal of Sustainable Development and Environmental Protection, 1(2), 6-17.

Famiyeh, S., Kwarteng, A., \& Dadzie, S. A. (2016). Corporate Social Responsibility and Reputation: Some Empirical Perspectives. Journal of Global Responsibility, 7(2), 258-274. https://doi.org/10.1108/JGR-042016-0009

Fang, S.-R., Huang, C.-Y., \& Huang, S. W.-L. (2010). Corporate Social Responsibility Strategies, Dynamic Capability and Organizational Performance: Cases of Top Taiwan-Selected Benchmark Enterprises. African Journal of Business Management, 4(1), 120-132.

Flammer, C. (2013). Corporate Social Responsibility and Shareholder Reaction: The Environmental Awareness of Investors. Academy of Management Journal, 56(3), 758-781. https://doi.org/10.5465/amj.2011.0744

Fleiss, J. L. (1971). Measuring Nominal Scale Agreement among Many Raters. Psychological Bulletin, 76(5), 378382. https://doi.org/10.1037/ho031619

Galbreath, J. (2009). Building Corporate Social Responsibility into Strategy. European Business Review, 21(2), 109-127. https://doi.org/10.1108/09555340910940123

Garcés-Ayerbe, C., Rivera-Torres, P., \& Murillo-Luna, J. L. (2012). Stakeholder Pressure and Environmental Proactivity: Moderating Effect of Competitive Advantage Expectations. Management Decision, 50(2), 189-206. https://doi.org/10.1108/00251741211203524

Groza, M. D., Pronschinske, M. R., \& Walker, M. (2011). Perceived Organizational Motives and Consumer Responses to Proactive and Reactive CSR. Journal of Business Ethics, 102(4), 639-652. https://doi.org/10.1007/s10551-011-0834-9

Haas, M. R., \& Hansen, M. T. (2005). When Using Knowledge Can Hurt Performance: The Value of Organizational Capabilities in a Management Consulting Company. Strategic Management Journal, 26(1), 1-24. https://doi.org/10.1002/smj.429

Henriques, I., \& Sadorsky, P. (1999). The Relationship Between Environmental Commitment and Managerial Perceptions of Stakeholder Importance. Academy of Management Journal, 42(1), 87-99. https://doi.org/10.5465/256876

Hossain, M. M., \& Alam, M. (2016). Corporate Social Reporting (CSR) and Stakeholder Accountability in Bangladesh: Perceptions of Less Economically Powerful Stakeholders. International Journal of Accounting and Information Management, 24(4), 415-442. https://doi.org/10.1108/IJAIM-05-2016-0064 
Hossain, M. M., Momin, M. A., Rowe, A. L., \& Quaddus, M. (2017). Corporate Social and Environmental Reporting Practices: A Case of Listed Companies in Bangladesh. Sustainability Accounting, Management and Policy Journal, 8(2), 138-165. https://doi.org/10.1108/SAMPJ-04-2015-0027

lacobucci, D., \& Churchill Jr., G. A. (2018). Marketing Research: Methodological Foundations (12th ed.). CreateSpace Publishing.

Jayanti, R. K., \& Gowda, M. V. R. (2014). Sustainability Dilemmas in Emerging Economies. IIMB Management Review, 26(2), 130-142. https://doi.org/10.1016/j.iimb.2014.03.004

Menguc, B., \& Ozanne, L. K. (2005). Challenges of the "Green Imperative": A Natural Resource-Based Approach to the Environmental Orientation-Business Performance Relationship. Journal of Business Research, 58(4), 430-438. https://doi.org/10.1016/j.jbusres.2003.09.002

Miles, M. B., Huberman, A. M., \& Saldana, J. (2013). Qualitative Data Analysis: A Methods Sourcebook (3rd ed.). London: SAGE Publications, Inc.

Oeyono, J., Samy, M., \& Bampton, R. (2011). An Examination of Corporate Social Responsibility and Financial Performance: A Study of The Top 50 Indonesian Listed Corporations. Journal of Global Responsibility, 2(1), 100-112. https://doi.org/10.1108/20412561111128555

Powell, T. C. (2001). Competitive Advantage: Logical and Philosophical Considerations. Strategic Management Journal, 22(9), 875-888. https://doi.org/10.1002/smj.173

Rasi, R. Z. R. M., Abdekhodaee, A., \& Nagarajah, R. (2014). Stakeholders' Involvements in the Implementation of Proactive Environmental Practices: Linking Environmental Practices and Environmental Performances in SMEs. Management of Environmental Quality: An International Journal, 25(2), 132-149. https://doi.org/10.1108/MEQ-11-2011-0054

Richards, L., \& Morse, J. M. (2012). README FIRST for a User's Guide to Qualitative Methods (3rd ed.). London: SAGE Publications, Inc.

Sambasivan, M., Bah, S. M., \& Jo-Ann, H. (2013). Making the Case for Operating "Green": Impact of Environmental Proactivity on Multiple Performance Outcomes of Malaysian Firms. Journal of Cleaner Production, 42, 69-82. https://doi.org/10.1016/j.jclepro.2012.11.016

Torugsa, N. A., O'Donohue, W., \& Hecker, R. (2013). Proactive CSR: An Empirical Analysis of the Role of its Economic, Social and Environmental Dimensions on the Association between Capabilities and Performance. Journal of Business Ethics, 115(2), 383-402. https://doi.org/10.1007/s10551-012-1405-4

Wagner, T., Lutz, R. J., \& Weitz, B. A. (2009). Corporate Hypocrisy: Overcoming the Threat of Inconsistent Corporate Social Responsibility Perceptions. Journal of Marketing, 73(6), 77-91. https://doi.org/10.1509/jmkg.73.6.77

Wang, H.-L. (2014). Theories for Competitive Advantage. In H. Hasan (Ed.), Being Practical with Theory: A Window into Business Research (pp. 33-43). Wollongong: THEORI.

Weng, H.-H., Chen, J.-S., \& Chen, P.-C. (2015). Effects of Green Innovation on Environmental and Corporate Performance: A Stakeholder Perspective. Sustainability, 7(5), 4997-5026. https://doi.org/10.3390/su7054997

Yin, R. K. (2017). Case Study Research and Applications: Design and Methods (6th ed.). London: SAGE Publications, Inc.

Yu, W., \& Ramanathan, R. (2016). Environmental Management Practices and Environmental Performance: The Roles of Operations and Marketing Capabilities. Industrial Management and Data Systems, 116(6), 12011222. https://doi.org/10.1108/IMDS-09-2015-0380 